Cite this: J. Mater. Chem. A, 2013, 1, 6901

Received 8th March 2013 Accepted 12th April 2013

DOI: $10.1039 /$ c3ta10986k

www.rsc.org/MaterialsA

\section{Carbon buffered-transition metal oxide nanoparticle- graphene hybrid nanosheets as high-performance anode materials for lithium ion batteries $\uparrow$}

\author{
Xin Huang, Jing Chen, Hong Yu, Ren Cai, Shengjie Peng, Qingyu Yan* \\ and Huey Hoon Hng*
}

In this article, we report a simple and general method for the synthesis of carbon buffered-metal oxide nanoparticle (NP)-graphene hybrid 2D nanosheets, which include $\mathrm{C}-\mathrm{SnO}_{2}-\mathrm{rGO}$ and $\mathrm{C}-\mathrm{Fe}_{2} \mathrm{O}_{3}-\mathrm{rGO}$ nanosheets. For the preparation of these anodes, tannic acid (TA), a kind of polyphenol extracted from plants, was used as a dispersing agent to introduce a metal precursor on the surface of $\mathrm{rGO}$, and the metal precursor was subsequently converted to the corresponding metal oxide NPs by thermal annealing in a vacuum. During the thermal annealing process, TA was decomposed to form carbon materials, which acted as a buffering matrix to effectively suppress the aggregation and pulverization of the active NPs during the electrochemical performances. It is found that the as-prepared $\mathrm{C}-\mathrm{SnO}_{2}-\mathrm{rGO}$ and $\mathrm{C}-\mathrm{Fe}_{2} \mathrm{O}_{3}-\mathrm{rGO}$ nanosheets both exhibited high reversible capacity and rate capability. After 100 discharge/charge cycles, the $\mathrm{C}-\mathrm{SnO}_{2}-\mathrm{rGO}$ nanosheet delivered the reversible capacity of $633.2 \mathrm{~mA} \mathrm{~h} \mathrm{~g}^{-1}$ at a current density of $200 \mathrm{~mA} \mathrm{~g}^{-1}$ with extremely low capacity fading $\left(0.32 \mathrm{~mA} \mathrm{~h} \mathrm{~g}^{-1}\right.$ per cycle), and it can deliver discharge capacities of $641.3,526.5,452.7,408.1$ and $379.5 \mathrm{~mA} \mathrm{~h} \mathrm{~g}^{-1}$ in the $10^{\text {th }}$ cycle at current densities of $200,400,800,1200$ and $1600 \mathrm{~mA} \mathrm{~g}^{-1}$, respectively. Upon return to a cycling rate of $200 \mathrm{~mA} \mathrm{~g}^{-1}$, the $\mathrm{C}-\mathrm{SnO}_{2}-\mathrm{rGO}$ can maintain a specific capacity of $607.0 \mathrm{~mA} \mathrm{~h} \mathrm{~g}^{-1}$ even after 35 cycles. As for the $\mathrm{C}-\mathrm{Fe}_{2} \mathrm{O}_{3}-\mathrm{rGO}$ nanosheet, it can deliver $504.1 \mathrm{~mA} \mathrm{~h} \mathrm{~g} \mathrm{~g}^{-1}$ at a current density of $500 \mathrm{~mA} \mathrm{~g}^{-1}$ after 100 cycles, and the corresponding discharge capacities in the $10^{\text {th }}$ cycle at current densities of 1000,1500 and $2000 \mathrm{~mA} \mathrm{~g}^{-1}$ are $365.9,319.0$ and $288.6 \mathrm{~mA} \mathrm{~h} \mathrm{~g}^{-1}$, respectively.

\section{Introduction}

There is great interest in developing lithium ion batteries (LIBs) because of the steadily growing demand for portable electronic devices. However, the graphite that is currently used as an anode in commercial LIBs has a low energy density $(372 \mathrm{~mA} \mathrm{~h}$ $\left.\mathrm{g}^{-1}\right),{ }^{1}$ which is insufficient to meet the demand for batteries with high energy density. Thus, exploring anode materials with high energy density to replace graphite is of key importance for the development of LIBs.

Transition metal oxides such as tin oxides, ${ }^{2,3}$ iron oxides ${ }^{4}$ and cobalt oxides ${ }^{5}$ have attracted tremendous attention as promising anode materials for the next generation of LIBs due to their high specific capacity and energy density. However, these anode materials would generally suffer large volume changes and stresses during lithium insertion/extraction processes, which cause serious cracking and pulverization of the electrode,

School of Materials Science and Engineering, Nanyang Technological University, 50 Nanyang Avenue, Singapore 639798. E-mail: alexyan@ntu.edu.sg; ashhhng@ntu. edu.sg

† Electronic supplementary information (ESI) available: UV-vis spectra, TGA and TEM analysis. See DOI: 10.1039/c3ta10986k and eventually lead to poor cycling performances. To solve these problems, one effective approach is to fabricate nanostructured materials modified with carbon. Downsizing particle size to the nanoscale can not only facilitate lithium ions to diffuse into the electrode matrix but also accommodate the physical strains associated with volume change. ${ }^{6-8}$ The use of carbon can effectively increase the electrode conductivity and prevent the detachment and agglomeration of pulverized active materials during cycling, thus leading to enhanced cycle life of the batteries.9-11 To date, various nanostructured metal oxidecarbon nanocomposites have been prepared. Among them, graphene-based meal oxide nanocomposites have been shown to be the most promising anode materials owing to the unique physiochemical properties of graphene. ${ }^{12}$

Graphene is a one-atom-thick two-dimensional carbon nanosheet (carbon atoms organized in a honeycomb structure), which has an excellent electrical conductivity (resistivity $=10^{-6} \Omega \mathrm{cm}$ ) and high theoretical surface area $\left(2600 \mathrm{~cm}^{2} \mathrm{~g}^{-1}\right) \cdot{ }^{13-15}$ Until now, a large number of nanostructured transition-metal oxide-graphene nanocomposites have been extensively investigated, ${ }^{\mathbf{1 6 - 2 1}}$ such as $\mathrm{SnO}_{2}$-graphene, CoO-graphene, $\mathrm{CuO}$-graphene, $\mathrm{Fe}_{2} \mathrm{O}_{3}$-grapheme and $\mathrm{TiO}_{2}$-graphene. Indeed, these hybrid nanocomposites exhibit 
much higher capacity and stability as compared with their bare counterparts. However, majority of these hybrid nanocomposites are prepared by direct host active nanomaterials on the surface of pristine graphene or graphene oxide (GO), followed by reduction of GO to reduced GO (rGO), where the deposited active nanoparticles will suffer irreversible aggregation or detachment during electrochemical cycles owing to the absence of stabilization by functional groups or buffering matrices among the active NPs. For example, ${ }^{22} \mathrm{Li}$ et al. reported a facile and efficient method for the synthesis of $\mathrm{SnO}_{2}$-grapheme nanosheet composites, which is based on the reduction of graphene oxide (GO) by $\mathrm{Sn}^{2+}$ ions. Due to the absence of a buffering carbon matrix, the as-prepared materials suffered a slow capacity fading, from 541.3 to $377.3 \mathrm{~mA} \mathrm{~h}$ $\mathrm{g}^{-1}$ even at a current density of $100 \mathrm{~mA} \mathrm{~g}^{-1}$. Paek and his coworkers prepared $\mathrm{SnO}_{2}$-graphene nanoporous electrodes $\left(\mathrm{SnO}_{2}-\mathrm{GNS}\right) .^{23}$ After 30 cycles, the charge capacity of $\mathrm{SnO}_{2}-$ GNS remained at $570 \mathrm{~mA} \mathrm{~h} \mathrm{~g}{ }^{-1}$, accounting only for $70 \%$ retention of the reversible capacity. To circumvent these obstacles, the possible solutions include chemical functionalization of graphene or buffering the active nanoparticles (NPs) by carbon materials. Considering that chemical functionalization of graphene may lead to the destruction of a long range $\pi$-conjugation, the latter alternative would be a more feasible strategy. Along this line, some important work has been pioneered for different anode materials systems (such as $\mathrm{Fe}_{3} \mathrm{O}_{4}$, Ge and $\mathrm{Si}$ ), ${ }^{\mathbf{2 4 - 2 6}}$ where the anode nanomaterials are confined within carbon shells, and then dispersed onto the flexible and conductive graphene.

In this article, we report a simple and general method for the synthesis of carbon buffered-transition-metal oxide NP-graphene hybrid nanosheets. Tannic acid (TA) is a typical polyphenol extracted from plants, which contains a number of pyrogallol hydroxyls that have strong chelating ability towards various transition metal ions with empty orbitals. Herein, TA was first chelated with transition-metal ions to ensure good dispersion of metal precursors on the surface of rGO. Subsequently, the metal precursors were converted to their corresponding metal oxide NPs via vacuum annealing, during which TA was simultaneously decomposed to carbon materials to buffer the metal oxide NPs. In this way, the metal oxide NPS can be firmly anchored onto the surface of the rGO without risking the destruction of the long range $\pi$-conjugation of the rGO. It can be expected that such well designed 2D hybrid nanocomposites can not only facilitate the rapid diffusion of lithium ions to the electrode but also effectively suppress the aggregation and pulverization of the active NPs due to the presence of buffering carbon materials. We chose to anchor carbon buffered-SnO $\mathrm{S}_{2} \mathrm{NPs}$ and $-\mathrm{Fe}_{2} \mathrm{O}_{3}$ NPs on the rGO for their high theoretical capacity. As expected, the as-prepared $\mathrm{C}-\mathrm{SnO}_{2}-\mathrm{rGO}$ and $\mathrm{C}-\mathrm{Fe}_{2} \mathrm{O}_{3}-\mathrm{rGO}$ nanosheets exhibited high reversible capacity, good cycling stability, and high rate capability. Considering the wide-ranging chelating ability of TA towards a variety of transition-metal ions, the approach demonstrated here can be extended to the fabrication of other carbon buffered metal oxide-graphene hybrid 2D nanocomposite anodes.

\section{Experimental section}

\section{Preparation of rGO}

GO was prepared from natural graphite by a modified Hummer's method. ${ }^{27,28}$ Subsequently, GO was dispersed in hydrazinewater solution $(1: 2, \mathrm{v} / \mathrm{v})$ to react at $100{ }^{\circ} \mathrm{C}$ for $24 \mathrm{~h}$. The product was isolated by centrifugation and fully washed with deionized water and ethanol. The obtained rGO black powder was dried in a vacuum oven at $50{ }^{\circ} \mathrm{C}$ for $24 \mathrm{~h}$.

\section{Preparation of $\mathrm{C}_{-} \mathrm{SnO}_{2}-\mathrm{rGO}$ nanosheets}

$8.0 \mathrm{mg}$ of tannic acid $\left(\mathrm{C}_{76} \mathrm{H}_{52} \mathrm{O}_{46}\right.$, Sigma-Aldrich) was dissolved in $1.0 \mathrm{~mL}$ of ethanol, and then $8.0 \mathrm{mg}$ of rGO was suspended in the above solution, followed by ultrasonication for $4 \mathrm{~h}$. After that, $1.0 \mathrm{~mL}$ of ethanol containing $104.2 \mathrm{mg}$ of tin(Iv) chloride hydrate $\left(\mathrm{SnCl}_{4} \cdot x \mathrm{H}_{2} \mathrm{O}\right.$, Alfa Aesar) was dropwise added into the above suspension. The resultant mixture was stirred for $2 \mathrm{~h}$, and then vacuum-dried at $50{ }^{\circ} \mathrm{C}$. The collected samples were vacuum annealed at $400{ }^{\circ} \mathrm{C}$ for $1.0 \mathrm{~h}$ (or at $500{ }^{\circ} \mathrm{C}$ for $2.0 \mathrm{~h}$ ). The obtained $\mathrm{C}-\mathrm{SnO}_{2}-\mathrm{rGO}$ nanosheet was thoroughly washed with deionized water and ethanol, followed by vacuum drying at $50{ }^{\circ} \mathrm{C}$.

\section{Preparation of $\mathrm{C}^{-\mathrm{Fe}_{2}} \mathrm{O}_{3}-\mathrm{rGO}$}

$8.0 \mathrm{mg}$ of rGO was mixed with $24 \mathrm{~mL}$ of ethanol, which contains $8.0 \mathrm{mg}$ of tannic acid. After ultrasonication for $4 \mathrm{~h}, 1.0 \mathrm{~mL}$ of ethanol containing $32.4 \mathrm{mg}$ of ferric chloride $\left(\mathrm{FeCl}_{3}\right.$, Alfa Aesar) was dropwise added into the above suspension, followed by constant stirring for $12 \mathrm{~h}$. The resultant materials were collected by centrifugation and thoroughly washed with deionized water and ethanol. After vacuum drying at $50{ }^{\circ} \mathrm{C}$, the intermediate materials were further vacuum annealed at $500{ }^{\circ} \mathrm{C}$ for $2.0 \mathrm{~h}$. The obtained C- $\mathrm{Fe}_{2} \mathrm{O}_{3}-\mathrm{rGO}$ nanosheet was thoroughly washed with deionized water and ethanol, and vacuum-dried at $50{ }^{\circ} \mathrm{C}$.

\section{Electrochemical measurement}

$70 \mathrm{wt} \%$ of the $\mathrm{C}-\mathrm{SnO}_{2}-\mathrm{rGO}$ nanosheet (or $\mathrm{C}-\mathrm{Fe}_{2} \mathrm{O}_{3}-\mathrm{rGO}$ nanosheet), $20 \mathrm{wt} \%$ of conductive carbon black, and $10 \mathrm{wt} \%$ of polyvinylidene fluoride (PVDF) binder were fully mixed into $N$-methyl2-pyrrolidinone (NMP). The resultant slurry was coated onto $\mathrm{Cu}$ foils, and vacuum-dried at $50{ }^{\circ} \mathrm{C}$ to completely remove the solvent. The electrochemical properties of the obtained working electrodes were measured using two-electrode CR2032 (3 V) cointype cells with lithium foil serving as both counter and reference electrodes at ambient temperature. The electrolyte was $1 \mathrm{M} \mathrm{LiPF}_{6}$ in a 50:50 (w/w) mixture of ethylene carbonate (EC) and dimethyl carbonate (DMC). Cell assembly was carried out in an argon-filled glove box with both moisture and oxygen contents below $1.0 \mathrm{ppm}$. Galvanostatic discharge/charge tests were performed using a NEWARE battery tester.

\section{Other characterizations}

Ultraviolet-visible (UV-vis) spectra analyses were conducted using a UV-vis spectrometer (Shimadzu UV-2501PC). Thermogravimetry analyses (TGA, Q500) were carried out in the 
temperature range $33-900{ }^{\circ} \mathrm{C}$ at a heating rate of $15^{\circ} \mathrm{C} \min ^{-1}$ in $\mathrm{N}_{2}$. The X-ray diffraction patterns of the samples were recorded using a Bruker D8 Advance diffractometer using $\mathrm{Cu} \mathrm{K} \alpha$ radiation. The morphology of the samples was characterized with a field emission scanning electron microscope (FESEM) system (JEOL, Model JSM-7600F) and a transmission electron microscope (TEM) system (JEOL, Model JEM-2010F) operating at 200 $\mathrm{kV}$. Raman spectra were obtained with a WITec CRM200 confocal Raman microscopy system.

\section{Results and discussion}

Due to the presence of pyrogallol hydroxyls in its molecule, TA is able to chelate with transition-metal ions with empty d-orbitals by donating a lone pair of electrons of the two adjacent phenolic oxygen molecules, which results in the formation of stable fivemembered chelating rings. ${ }^{29-31}$ To verify the chelating reactions of TA toward $\mathrm{Sn}^{4+}$ and $\mathrm{Fe}^{3+}$, UV-visible spectra of TA before and after the reaction with $\mathrm{Sn}^{4+}$ and $\mathrm{Fe}^{3+}$ were recorded. As shown in ESI S1, $\uparrow$ pure TA shows an intensive characteristic adsorption peak at $278 \mathrm{~nm}$. After mixing with $\mathrm{Sn}^{4+}$ in ethanol, the specific adsorption peak of tannic acid exhibits a red-shift from $278 \mathrm{~nm}$ to $303 \mathrm{~nm}$, which confirms the chelating interactions between tannic acid and $\mathrm{Sn}^{4+}$. As for the chelating interactions between TA and $\mathrm{Fe}^{3+}$, a specific adsorption peak of TA- $\mathrm{Fe}^{3+}$ was observed at $600 \mathrm{~nm}$ after the mixing of TA with $\mathrm{Fe}^{3+}$.

Moreover, the reaction is extremely fast, which is accompanied by an immediate color change from light yellow to dark blue. Actually, the stability constant of $\mathrm{TA}-\mathrm{Fe}^{3+}$ is high up to $10^{30}-10^{50},{ }^{32}$ and the chelating reaction between TA and $\mathrm{Fe}^{3+}$ has already been utilized as an effective staining method for mammalian tissue. ${ }^{33}$ Scheme 1 shows the proposed preparation mechanism of the $\mathrm{C}-\mathrm{SnO}_{2}-\mathrm{rGO}$ and $\mathrm{C}-\mathrm{Fe}_{2} \mathrm{O}_{3}-\mathrm{rGO}$ nanosheets. For the preparation of the $\mathrm{C}-\mathrm{SnO}_{2}-\mathrm{rGO}$ nanosheet, TA plays the role as a dispersing agent as well as the source of the carbon buffering matrix. TA- $\mathrm{Sn}^{4+}$ precursors were first impregnated on rGO. During this process, TA acts as a dispersing agent to ensure good dispersion of TA- $\mathrm{Sn}^{4+}$ on the surface of rGO owing to the noncovalent $\pi-\pi$ stacking interactions between the aromatic rings of TA and $\mathrm{rGO}^{34}$ Subsequently, the $\mathrm{Sn}^{4+}$ precursors were converted to $\mathrm{SnO}_{2}$ NPs by thermal annealing at high temperature in a vacuum. According to TGA in a $\mathrm{N}_{2}$ flow (ESI, S2 $\dagger$ ), the weight loss of TA is higher than $60 \%$ when the temperature is beyond $400{ }^{\circ} \mathrm{C}$. Hence, the TA molecules that are chelated with $\mathrm{Sn}^{4+}$ precursors will decompose to a carbon matrix when thermally annealed at high temperature in a vacuum, which can act as a buffering matrix to effectively suppress the aggregation of the $\mathrm{SnO}_{2}$ NPs. Moreover, the high temperature annealing can ensure firm anchoring of the carbon buffered-SnO $\mathrm{O}_{2} \mathrm{NPs}$ on the surface of rGO. In this way, a C-SnO ${ }_{2}^{-}$ rGO nanosheet with high stability was prepared. The $\mathrm{C}-\mathrm{Fe}_{2} \mathrm{O}_{3}-$ rGO nanosheet shares the same preparation mechanism with the $\mathrm{C}-\mathrm{SnO}_{2}-\mathrm{rGO}$ nanosheet.

We first prepared the $\mathrm{C}-\mathrm{SnO}_{2}-\mathrm{rGO}$ nanosheet by vacuum annealing the precursor at $500{ }^{\circ} \mathrm{C}$, the corresponding XRD pattern of which, ESI S3, $\dagger$ exhibits intensive characteristic peaks of $\mathrm{SnO}_{2}$ (JCPDS no. 41-1445) at $25.5^{\circ}$ (110), $33.8^{\circ}$ (101), 51.6 (211) and $66^{\circ}(301) .{ }^{22}$ In general, tin oxide with high crystallinity is more likely to suffer structural collapse during charge/ discharge processes as compared with the amorphous counterpart. ${ }^{16}$ In order to decrease the crystallinity of the $\mathrm{SnO}_{2} \mathrm{NPs}$, the annealing temperature was reduced to $400{ }^{\circ} \mathrm{C}$. As shown in ESI $\mathrm{S} 3, \dagger$ the obtained sample still exhibits the characteristic peaks of $\mathrm{SnO}_{2}$ but these peaks are considerably broadened, and the peak intensity is much weak in comparison to those samples at $500{ }^{\circ} \mathrm{C}$, which therefore indicate that the as-prepared $\mathrm{C}^{-} \mathrm{SnO}_{2}$ NPs have lower crystallinity (higher content of amorphous phase) and smaller particle size. The XRD patterns of the $\mathrm{C}-\mathrm{Fe}_{2} \mathrm{O}_{3}-\mathrm{rGO}$ nanosheet at $500{ }^{\circ} \mathrm{C}$ are shown in ESI S3, $\dagger$ which show the characteristic peaks of $\alpha-\mathrm{Fe}_{2} \mathrm{O}_{3}$ with high intensity, ${ }^{35}$ thus suggesting that the C-buffered $\alpha-\mathrm{Fe}_{2} \mathrm{O}_{3}$ NPs have been successfully anchored onto the rGO.

The scanning electron microscopy (SEM) images of the $\mathrm{C}-\mathrm{SnO}_{2}-\mathrm{rGO}$ at $400{ }^{\circ} \mathrm{C}$ and $\mathrm{C}-\mathrm{Fe}_{2} \mathrm{O}_{3}-\mathrm{rGO}$ at $500{ }^{\circ} \mathrm{C}$ are shown in Fig. 1. It is observed that the $\mathrm{SnO}_{2}$ NPs and $\mathrm{Fe}_{2} \mathrm{O}_{3}$ NPs are successfully anchored onto the surface of the rGO nanosheet. For the $\mathrm{C}-\mathrm{SnO}_{2}-\mathrm{rGO}$ nanosheet, the $\mathrm{C}-\mathrm{SnO}_{2}$ NPs exhibit a homogeneous dispersion on the surface of the rGO without significant aggregation, and the particle size of the $\mathrm{C}^{-\mathrm{SnO}_{2}} \mathrm{NPS}$ is quite small, which is in the range of 5-15 $\mathrm{nm}$. In general, small NPs have a high tendency to self-aggregate, but the carbon buffering matrix derived from the decomposition of

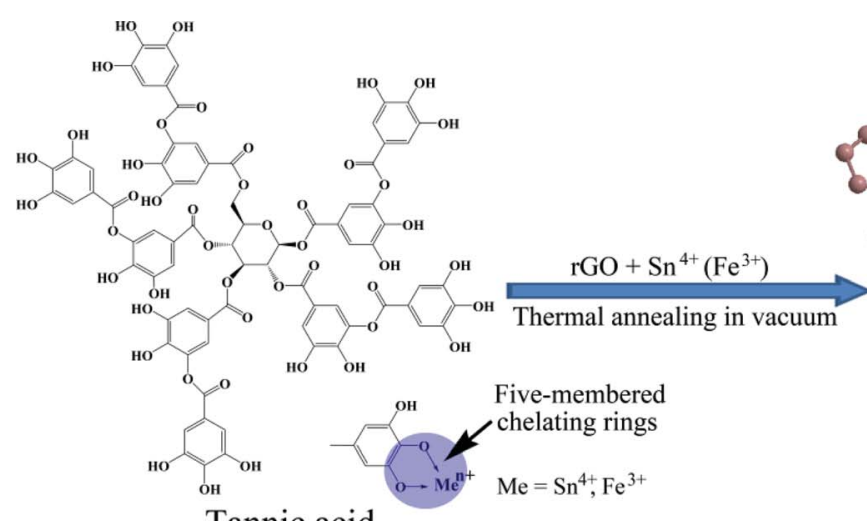

Tannic acid

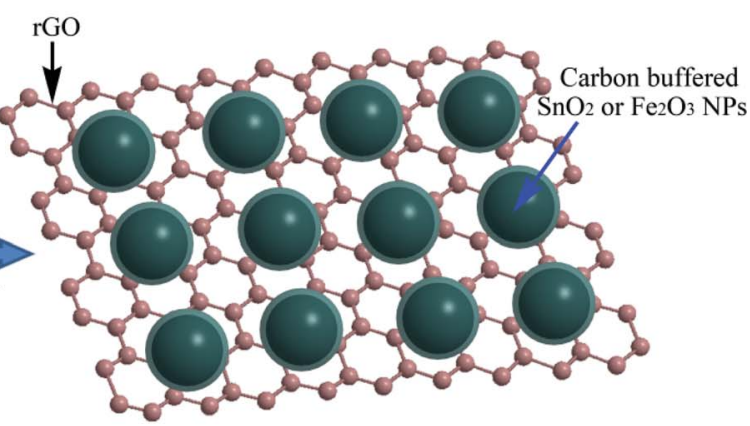

$\mathrm{C}-\mathrm{SnO}_{2}$ (or $\mathrm{C}-\mathrm{Fe}_{2} \mathrm{O}_{3}$ )-rGO nanosheet

Scheme 1 The proposed preparation mechanism of the $\mathrm{C}-\mathrm{SnO}_{2}-\mathrm{rGO}$ and $\mathrm{C}-\mathrm{Fe}_{2} \mathrm{O}_{3}-\mathrm{rGO}$ nanosheets. 


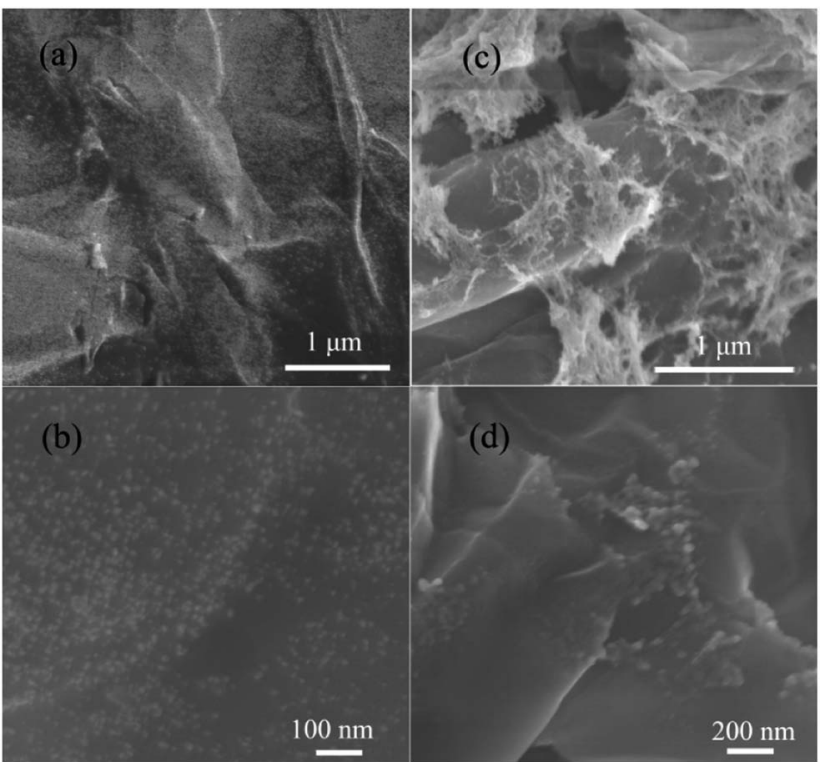

Fig. 1 Scanning electron microscopy (SEM) images of the $\mathrm{C}-\mathrm{SnO}_{2}-\mathrm{rGO}$ ( $\mathrm{a}$ and $\mathrm{b}$ ) and the $\mathrm{C}-\mathrm{Fe}_{2} \mathrm{O}_{3}-\mathrm{rGO}$ nanosheets (c and d) with different magnifications.

TA effectively suppresses $\mathrm{SnO}_{2}$ NPs from aggregating. The $\mathrm{C}-\mathrm{Fe}_{2} \mathrm{O}_{3}-\mathrm{rGO}$ nanosheet shows a similar morphology. In Fig. 1c, the morphology of rGO nanosheets is clearly observed, where small $\mathrm{Fe}_{2} \mathrm{O}_{3}$ NPs $(10-20 \mathrm{~nm})$ are anchored. At higher magnification, it is found that the $\mathrm{Fe}_{2} \mathrm{O}_{3}$ NPs anchored onto the surface of the rGO nanosheet have a closely packed arrangement but serious aggregation is rarely found. This should also be attributed to the formation of a carbon buffering matrix among the $\mathrm{Fe}_{2} \mathrm{O}_{3}$ NPs.

The transmission electron microscopy (TEM) images of the $\mathrm{C}-\mathrm{SnO}_{2}-\mathrm{rGO}$ nanosheet with different magnifications are given in Fig. 2a and b. Although a strong ultrasonic treatment was applied during preparation of the TEM samples, it is seen that the entire rGO nanosheet is still fully decorated by small $\mathrm{SnO}_{2}$ NPs. This indicates that the $\mathrm{C}_{-} \mathrm{SnO}_{2}$ NPs are firmly anchored onto the surface of the $\mathrm{rGO}$ nanosheet. In ESI S4, $\uparrow \mathrm{C}-\mathrm{SnO}_{2}-\mathrm{rGO}$ at $500{ }^{\circ} \mathrm{C}$ shows similar TEM images with the sample at $400{ }^{\circ} \mathrm{C}$ but these $\mathrm{SnO}_{2}$ NPs have a more packed arrangement on the surface of the rGO, which is possibly caused by the higher thermal annealing temperature. The high resolution TEM (HR-TEM) image of the $\mathrm{C}-\mathrm{Fe}_{2} \mathrm{O}_{3}-\mathrm{rGO}$ at $500{ }^{\circ} \mathrm{C}$ shows clear lattices, which suggest that $\mathrm{SnO}_{2} \mathrm{NPs}$ with high crystallinity are formed on the rGO. These results are consistent with the XRD analyses.

In Fig. 2c, the $\mathrm{C}_{-} \mathrm{Fe}_{2} \mathrm{O}_{3}-\mathrm{rGO}$ nanosheet shows similar TEM images with $\mathrm{C}-\mathrm{SnO}_{2}-\mathrm{rGO}$ at $500{ }^{\circ} \mathrm{C}$. The $\mathrm{Fe}_{2} \mathrm{O}_{3}$ NPs still exhibit a packed arrangement on the surface of the rGO. In Fig. 2d, the HR-TEM image of the $\mathrm{Fe}_{2} \mathrm{O}_{3}-\mathrm{rGO}$ nanosheet shows clear lattices, which confirms the formation of $\mathrm{Fe}_{2} \mathrm{O}_{3}$ NPs with high crystallinity. The corresponding Raman spectra of $\mathrm{C}-\mathrm{SnO}_{2}-\mathrm{rGO}$ at $400{ }^{\circ} \mathrm{C}$ and $\mathrm{C}-\mathrm{Fe}_{2} \mathrm{O}_{3}-\mathrm{rGO}$ at $500{ }^{\circ} \mathrm{C}$ are shown in Fig. 3 . Compared with $\mathrm{rGO}, \mathrm{C}-\mathrm{SnO}_{2}-\mathrm{rGO}$ and $\mathrm{C}-\mathrm{Fe}_{2} \mathrm{O}_{3}-\mathrm{rGO}$ nanosheets both contain $\mathrm{D}$ and $\mathrm{G}$ bands of the $\mathrm{rGO},{ }^{36}$ which suggest that no serious damage was incurred to the extended $\pi$-conjugation of

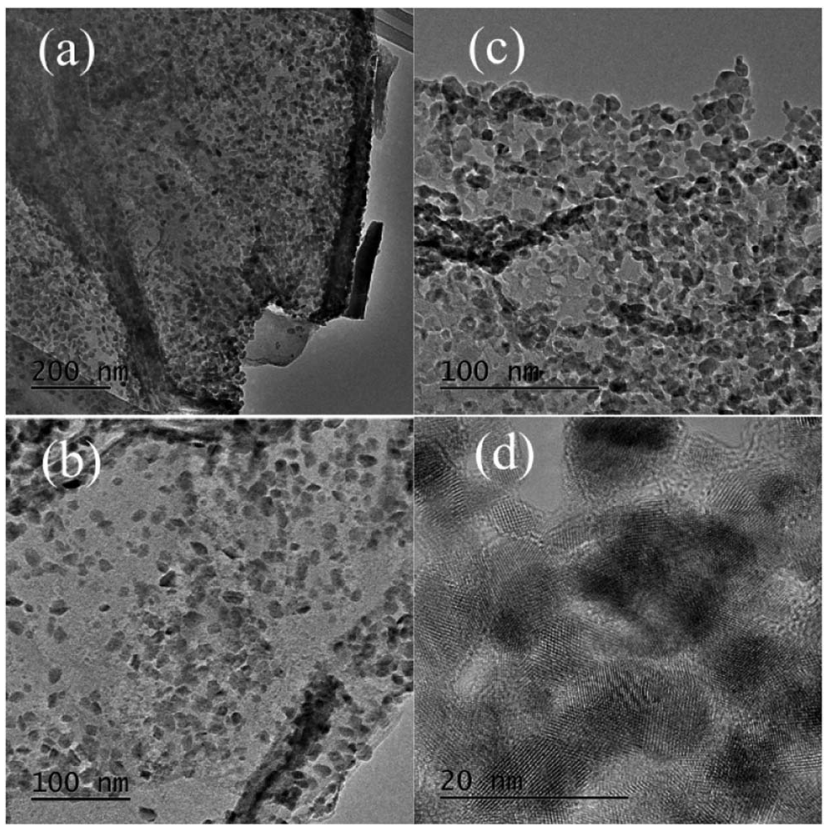

Fig. 2 Transmission electron microscopy (TEM) images of the $\mathrm{C}-\mathrm{SnO}_{2}-\mathrm{rGO}$ at $400{ }^{\circ} \mathrm{C}$ ( $a$ and $b$ ) and the $\mathrm{C}-\mathrm{Fe}_{2} \mathrm{O}_{3}-\mathrm{rGO}$ at $500{ }^{\circ} \mathrm{C}$ ( $\mathrm{c}$ and d) with different magnifications.

rGO when preparing the nanocomposites, and this will be beneficial for achieving good anode performances.

The Li storage properties of the $\mathrm{C}-\mathrm{SnO}_{2}-\mathrm{rGO}$ and $\mathrm{C}-\mathrm{Fe}_{2} \mathrm{O}_{3}-$ rGO nanosheets were examined using coin-type half-cells with a Li counter electrode and reference electrode. Fig. $4 \mathrm{a}$ and $\mathrm{b}$ show the galvanostatic discharge and charge voltage profiles generated by the $\mathrm{C}-\mathrm{SnO}_{2}-\mathrm{rGO}$ prepared at $500{ }^{\circ} \mathrm{C}$ and $400{ }^{\circ} \mathrm{C}$ in the $1^{\text {st }}$, $2^{\text {nd }}$ and $100^{\text {th }}$ cycles at a current density of $200 \mathrm{~mA} \mathrm{~g}^{-1}$ in the voltage window of $0.005-3.0 \mathrm{~V}$. The discharge and charge capacities of the $\mathrm{C}^{-} \mathrm{SnO}_{2}-\mathrm{rGO}$ at $500{ }^{\circ} \mathrm{C}$ are 1085.5 and $615.9 \mathrm{~mA}$ $\mathrm{h} \mathrm{g}^{-1}$ in the $1^{\text {st }}$ cycle, respectively, which indicate that the

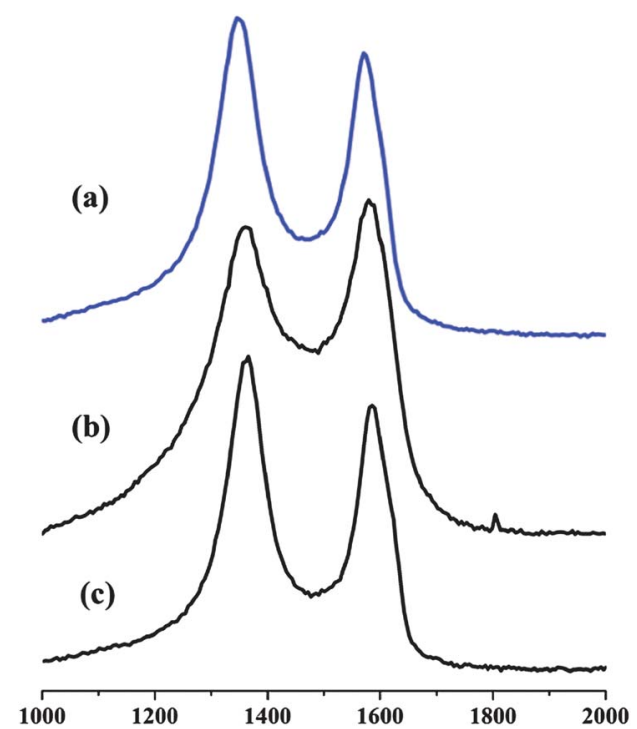

Fig. 3 Raman spectra of the $\mathrm{rGO}(\mathrm{a}), \mathrm{C}-\mathrm{SnO}_{2}-\mathrm{rGO}$ nanosheet at $400{ }^{\circ} \mathrm{C}(\mathrm{b})$ and $\mathrm{C}-\mathrm{Fe}_{2} \mathrm{O}_{3}-\mathrm{rGO}$ at $500{ }^{\circ} \mathrm{C}$ (c). 

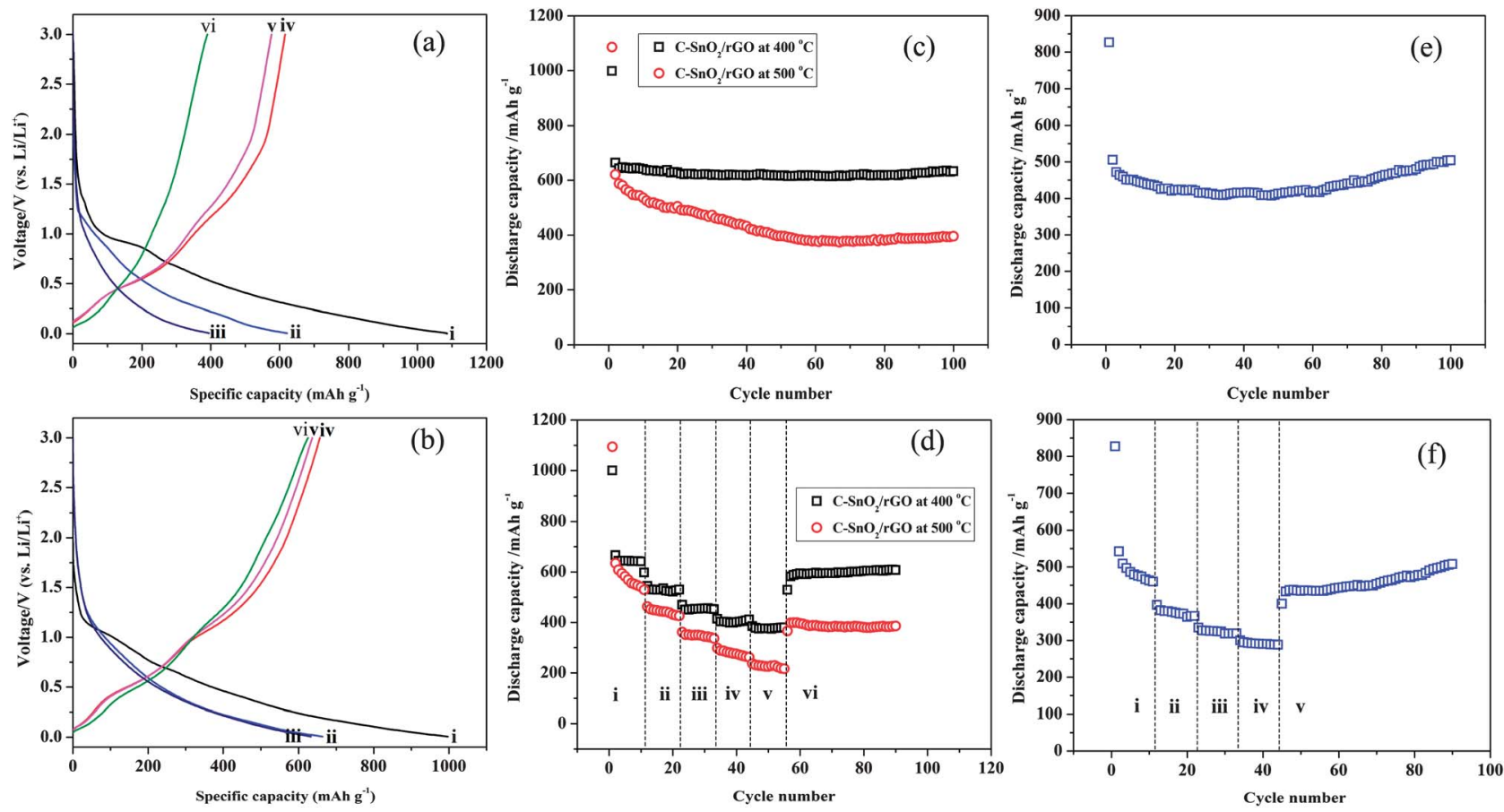

Fig. 4 Discharge/charge profiles of the $\mathrm{C}-\mathrm{SnO}_{2}-\mathrm{rGO}$ nanosheet at $500{ }^{\circ} \mathrm{C}(\mathrm{a})$ and $400{ }^{\circ} \mathrm{C}(\mathrm{b})$ at a current density of $200 \mathrm{~mA} \mathrm{~g}^{-1}$ in a voltage window of $0.005-3.00 \mathrm{~V}$ : the discharge curves in the (i) $1^{\text {st }}$, (ii) $2^{\text {nd }}$ and (iii) $100^{\text {th }}$ cycles, and the charge curves in the (iv) $1^{\text {st }}$, (v) $2^{\text {nd }}$ and (vi) $100^{\text {th }}$ cycles. Discharge capacities against cycle numbers

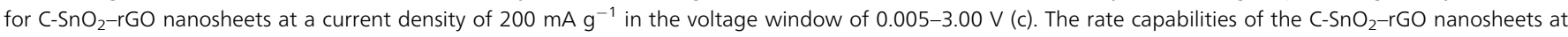
different current densities (d): (i) 200, (ii) 400, (iii) 800, (iv) 1200, (v) 1600 and (vi) $200 \mathrm{~mA} \mathrm{~g}^{-1}$. Discharge capacities against cycle numbers for the C-Fe $\mathrm{O}_{3}-\mathrm{rGO}$ nanosheet at a current density of $500 \mathrm{~mA} \mathrm{~g}^{-1}$ in the voltage window of $0.005-3.00 \mathrm{~V}$ (e). The rate capability of the C-Fe $\mathrm{O}_{3}-\mathrm{rGO}$ nanosheet at different current densities (f): (i) 500, (ii) 1000, (iii) 1500, (iv) 2000 and (v) $500 \mathrm{~mA} \mathrm{~g}^{-1}$.

corresponding coulombic efficiency is $56.74 \%$, and it can deliver a reversible discharge capacity of $621.3 \mathrm{~mA} \mathrm{~h} \mathrm{~g}^{-1}$ in the $2^{\text {nd }}$ cycle. As for the $\mathrm{C}-\mathrm{SnO}_{2}-\mathrm{rGO}$ at $400{ }^{\circ} \mathrm{C}$, its discharge and charge capacities are 997.6 and $656.9 \mathrm{~mA} \mathrm{~h} \mathrm{~g}^{-1}$ in the $1^{\text {st }}$ cycle, respectively, with an initial coulombic efficiency of $65.85 \%$, and a reversible discharge capacity of $664.6 \mathrm{~mA} \mathrm{~h} \mathrm{~g}^{-1}$ is delivered in the $2^{\text {nd }}$ cycle. According to the literature, ${ }^{37,38}$ Sn-based anode materials usually exhibit a large initial irreversible loss, which is often related to the formation of a solid electrolyte interface (SEI) layer on the anode surface and the decomposition of the electrolyte. In the $100^{\text {th }}$ cycle, the discharge voltage profile of the $\mathrm{C}-\mathrm{SnO}_{2}-\mathrm{rGO}$ at $500{ }^{\circ} \mathrm{C}$ is dropped more rapidly compared to the $1^{\text {st }}$ cycle. In comparison, the $\mathrm{C}-\mathrm{SnO}_{2}-\mathrm{rGO}$ at $400{ }^{\circ} \mathrm{C}$ delivered a discharge capacity of 633.2 in the $100^{\text {th }}$ cycle, and the corresponding discharge voltage profile almost overlaps with that of the $1^{\text {st }}$ cycle.

Fig. 4c presents the cyclic performance of the $\mathrm{C}-\mathrm{SnO}_{2}-\mathrm{rGO}$ at a current density of $200 \mathrm{~mA} \mathrm{~g}^{-1}$ in the voltage window of 0.005-3.0 V. The $\mathrm{C}^{-\mathrm{SnO}_{2}}-\mathrm{rGO}$ at $500{ }^{\circ} \mathrm{C}$ exhibits a slow but constant reversible capacity fading along with the cycling, which delivers a discharge capacity of $395.5 \mathrm{~mA} \mathrm{~g}^{-1}$ in the $100^{\text {th }}$ cycle, with a capacity fading of $2.28 \mathrm{~mA} \mathrm{~h} \mathrm{~g}{ }^{-1}$ per cycle on average. The $\mathrm{C}^{-\mathrm{SnO}_{2}}-\mathrm{rGO}$ prepared at $400{ }^{\circ} \mathrm{C}$ shows superior cycling stability compared to the sample prepared at $500{ }^{\circ} \mathrm{C}$. This nanocomposite worked pretty stably with the capacity of $633.2 \mathrm{~mA} \mathrm{~h}^{-1}$ in the $100^{\text {th }}$ cycle, which retains almost $95.28 \%$ of the $2^{\text {nd }}$ cycle capacity, with a negligible capacity fading (0.32 $\mathrm{mA} \mathrm{h} \mathrm{g}^{-1}$ per cycle on average), thus exhibiting excellent cycle performance. The cycling stability of the $\mathrm{C}-\mathrm{SnO}_{2}-\mathrm{rGO}$ at $400{ }^{\circ} \mathrm{C}$ was also obtained in the voltage window of $0.02-1.5 \mathrm{~V}$ at a current density of $400 \mathrm{~mA} \mathrm{~g}^{-1}$ (ESI S5 $\dagger$ ). In this narrow voltage window, the anode materials still deliver a high reversible capacity of $400.3 \mathrm{~mA} \mathrm{~h} \mathrm{~g}^{-1}$ in the $40^{\text {th }}$ cycle, suggesting its potential application in full cell batteries.

The rate capability is an important parameter for lithium ion batteries, and thus, the electrochemical performances of the C$\mathrm{SnO}_{2}-\mathrm{rGO}$ at $500{ }^{\circ} \mathrm{C}$ and $400{ }^{\circ} \mathrm{C}$ are measured at current densities of 200, 400, 800, 1200, 1600 and $200 \mathrm{~mA} \mathrm{~g}^{-1}$, respectively. As shown in Fig. 4 d, the $\mathrm{C}-\mathrm{SnO}_{2}-\mathrm{rGO}$ at $500{ }^{\circ} \mathrm{C}$ delivers discharge capacities of 540.1, 428.0, 339.8, 264.1 and $218.1 \mathrm{~mA}$ $\mathrm{h} \mathrm{g}^{-1}$ in the $10^{\text {th }}$ cycle at current densities of $200,400,800,1200$ and $1600 \mathrm{~mA} \mathrm{~g}^{-1}$, respectively. When the current density is decreased from 1600 to $200 \mathrm{~mA} \mathrm{~g}{ }^{-1}$, the discharge capacity could increase back to $\sim 400 \mathrm{~mA} \mathrm{~h} \mathrm{~g}{ }^{-1}$. As for the $\mathrm{C}_{-} \mathrm{SnO}_{2}-\mathrm{rGO}$ at $400{ }^{\circ} \mathrm{C}$, it maintains a steady discharge capacity at every current density, and the corresponding discharge capacities in the $10^{\text {th }}$ cycle are 641.3, 526.5, 452.7, 408.1 and $379.5 \mathrm{~mA} \mathrm{~h} \mathrm{~g}{ }^{-1}$, respectively. Upon return to a cycling rate of $200 \mathrm{~mA} \mathrm{~g}^{-1}$, the specific capacity of the anode is increased to $581.7 \mathrm{~mA} \mathrm{~h} \mathrm{~g}^{-1}$, and it can maintain a stable discharge capacity of $607.0 \mathrm{~mA} \mathrm{~g}^{-1}$ even after 35 cycles. As a consequence, the $\mathrm{C}_{-} \mathrm{SnO}_{2}-\mathrm{rGO}$ at $400{ }^{\circ} \mathrm{C}$ is promising to be stably operated at high discharge rate. Obviously, the $\mathrm{C}^{-} \mathrm{SnO}_{2}-\mathrm{rGO}$ nanosheet with low crystallinity prepared at $400{ }^{\circ} \mathrm{C}$ exhibits better cycling stability and rate capability than the sample with higher degree of crystallinity prepared at $500{ }^{\circ} \mathrm{C}$. According to the literature, ${ }^{39,40}$ it is likely 
that the $\mathrm{C}-\mathrm{SnO}_{2}-\mathrm{rGO}$ with low degree of crystallinity was less dense than its counterpart with higher crystallinity, which is associated with a homogenous volume expansion and contraction, thus eliminating the existence of two phase regions and improving the cycling stability. Consequently, the excellent electrochemical performances of the $\mathrm{C}-\mathrm{SnO}_{2}-\mathrm{rGO}$ nanosheet at $400{ }^{\circ} \mathrm{C}$ should be attributed to three factors: (1) the presence of a carbon buffering matrix considerably suppresses the fraction of $\mathrm{SnO}_{2}$ NPs to lose their electrical contact with rGO. (2) The rGO nanosheet provides good electronic conductivity and buffering effect to some extent. (3) The $\mathrm{SnO}_{2}$ NPs with low crystallinity accommodate the substantial volume changes to some extent.

The cycling stability and rate capability of the $\mathrm{C}-\mathrm{Fe}_{2} \mathrm{O}_{3}-\mathrm{rGO}$ nanosheet are shown in Fig. $4 \mathrm{e}$ and f. In Fig. 4e, the C-Fe ${ }_{2} \mathrm{O}_{3}-\mathrm{rGO}$ shows good stability at a current density of $500 \mathrm{~mA} \mathrm{~g}^{-1}$. In the $100^{\text {th }}$ cycle, the discharge capacity of the anode is $504.1 \mathrm{~mA} \mathrm{~h} \mathrm{~g}^{-1}$, which accounts for $99.62 \%$ of the capacity in the $2^{\text {nd }}$ cycle, thus exhibiting an excellent cycling stability. As seen in Fig. 4f, the C$\mathrm{Fe}_{2} \mathrm{O}_{3}$-rGO delivers discharge capacities of 463.0, 365.9, 319.0 and $288.6 \mathrm{~mA} \mathrm{~h} \mathrm{~g}^{-1}$ in the $10^{\text {th }}$ cycle at current densities of 500, 1000, 1500 and $2000 \mathrm{~mA} \mathrm{~g}^{-1}$, respectively, and the cycling performance is very stable at each discharge rate. The discharge capacity of the $\mathrm{C}-\mathrm{Fe}_{2} \mathrm{O}_{3}-\mathrm{rGO}$ can maintain at $508 \mathrm{~mA} \mathrm{~h} \mathrm{~g}^{-1}$ in the $45^{\text {th }}$ cycle when the current density is decreased from 2000 to 500 $\mathrm{mA} \mathrm{g}^{-1}$, which also exhibited an excellent rate capability.

\section{Conclusion}

We have developed a simple and general method for the synthesis of carbon buffered-transition metal oxide NP-graphene hybrid 2D nanosheets, where tannic acid is used as a dispersing agent as well as the source of buffering carbon. Due to the presence of a carbon buffering matrix, the $\mathrm{SnO}_{2} \mathrm{NPs}$ and $\mathrm{Fe}_{2} \mathrm{O}_{3}$ NPs can be stably anchored onto the surface of rGO without obvious aggregation. Moreover, the carbon buffering matrix can effectively accommodate the substantial volume changes of the active NPs, and accordingly, the as-prepared C$\mathrm{SnO}_{2}-\mathrm{rGO}$ and $\mathrm{C}-\mathrm{Fe}_{2} \mathrm{O}_{3}-\mathrm{rGO}$ nanosheets both exhibited excellent cycling stability and rate capability. It should be noted that this strategy could be extended to the synthesis of other hybrid 2D nanosheets due to the strong chelating ability of TA towards a variety of transition-metal ions.

\section{Acknowledgements}

This work was supported by the Singapore Ministry of Education (MOE2010-T2-1-017), A*STAR SERC grant 1021700144, NRF2009 EWT-CERP001-026 (Singapore), Singapore National Research Foundation under the CREATE program: EMobility in Megacities and Singapore MPA 23/04.15.03 RDP 020/10/113 grant.

\section{Notes and references}

1 Y. Idota, T. Kubota, A. Matsufuji, Y. Maekawa and T. Miyasaka, Science, 1997, 276, 1395.

2 C. A. Bonino, L. W. Ji, Z. Lin, Ozan, Toprakci, X. W. Zhang and S. A. Khan, ACS Appl. Mater. Interfaces, 2011, 3, 2534.
3 Y. Yu, C.-H. Chen and Y. Shi, Adv. Mater., 2007, 19, 993.

4 M. V. Reddy, T. Yu, C.-H. Sow, Z. X. Shen, C. T. Lim, G. V. Subba Rao and B. V. R. Chowdari, Adv. Funct. Mater., 2007, 17, 2792.

5 Y. M. Sun, X. L. Hu, W. Luo and Y. H. Huang, J. Phys. Chem. C, 2012, 116, 20794.

6 W. J. Zhang, J. Power Sources, 2011, 196, 13.

7 X. J. Zhu, Y. W. Zhu, S. Murali, M. D. Stollers and R. S. Ruoff, ACS Nano, 2011, 5, 3333.

8 Y. G. Guo, J. S. Hu and L. J. Wan, Adv. Mater., 2008, 20, 2878.

9 W. M. Zhang, J. S. Hu, Y. G. Guo, S. F. Zheng, L. S. Zhong,

W. G. Song and L. J. Wan, Adv. Mater., 2008, 20, 1160.

10 H. Q. Li and H. S. Zhou, Chem. Commun., 2012, 48, 1201.

11 Z. S. Wu, W. C. Ren, L. Wen, L. B. Gao, J. P. Zhao, Z. P. Chen,

G. M. Zhou, F. Li and H. M. Cheng, ACS Nano, 2010, 4, 3187.

12 X. Huang, Z. Y. Zeng, Z. X. Fan, J. Q. Liu and H. Zhang, Adv. Mater., 2012, 24, 5979.

13 H. X. Chang and H. K. Wu, Adv. Funct. Mater., 2012, 23, 1984. 14 A. H. Castro Neto, F. Guinea, N. M. R. Peres, K. S. Novoselov and A. K. Geim, Rev. Mod. Phys., 2009, 81, 109.

15 D. Chen, L. Tang and J. Li, Chem. Soc. Rev., 2010, 39, 3157. 16 X. F. Li, X. B. Meng, J. Liu, D. S. Geng, Y. Zhang, M. N. Banis, Y. L. Li, J. L. Yang, R. Y. Li, X. L. Sun, M. Cai and M. W. Verbrugge, Adv. Funct. Mater., 2012, 22, 1647.

17 F. D. Wu and Y. Wang, J. Mater. Chem., 2011, 21, 6636.

18 J. Y. Xiang, J. P. Tu, L. Zhang, Y. Zhou, X. L. Wang and S. J. Shi, J. Power Sources, 2010, 195, 313.

19 W. W. Zhou, J. X. Zhu, C. W. Cheng, J. P. Liu, H. P. Yang, C. X. Cong, C. Guan, X. T. Jia, H. J. Fan, Q. Y. Yan, C. M. Li and T. Yu, Energy Environ. Sci., 2011, 4, 4954.

20 D. H. Wang, R. Kou, D. Choi, Z. G. Yang, Z. M. Nie, J. Li, L. V. Saraf, J. G. Zhang, G. L. Graff, J. Liu, M. A. Pope and I. A. Aksay, ACS Nano, 2010, 4, 1587.

21 D. H. Wang, D. Choi, J. Li, Z. G. Yang, Z. M. Nie, R. Kou, D. H. Hu, C. M. Wang, L. V. Saraf, J. G. Zhang, I. A. Aksay and J. Liu, ACS Nano, 2009, 3, 907.

22 Y. M. Li, X. J. Lv, J. Lu and J. H. Li, J. Phys. Chem. C, 2010, 114, 21770.

23 S. M. Paek, E. J. Yoo and I. Honma, Nano Lett., 2009, 9, 72.

24 B. J. Li, H. Q. Cao, J. Shao and M. Z. Qu, Chem. Commun., 2011, 47, 10374.

25 D. J. Xue, S. Xin, Y. Yan, K. C. Jiang, Y. X. Yin, Y. G. Guo and L. J. Wan, J. Am. Chem. Soc., 2012, 134, 2512.

26 B. Wang, X. L. Li, X. F. Zhang, B. Luo, M. H. Jin, M. H. Liang, S. A. Dayeh, S. T. Picraux and L. J. Zhi, ACS Nano, 2013, 7, 1437.

27 W. S. Hummers and R. E. Offeman, J. Am. Chem. Soc., 1958, 80, 1339.

28 Y. X. Xu, H. Bai, G. W. Lu, C. Li and G. Q. Shi, J. Am. Chem. Soc., 2008, 130, 5856.

29 S. Quideau, D. Deffieux, C. D. Deffieux and L. Pouysegu, Angew. Chem., Int. Ed., 2011, 50, 586.

30 G. Tondi, C. W. Oo, A. Pizzi, A. Trosa and M. F. Thevenon, Ind. Crops Prod., 2009, 29, 336.

31 X. M. Zhan and X. Zhao, Water Res., 2003, 37, 3905.

32 I. A. T. Khan and Z. T. Maqsood, Sci. Iran., 2007, 14, 106.

33 T. D. Pizzolato, Bull. Torrey Bot. Club, 1977, 104, 277. 
34 P. Petrov, F. Stassin, C. Pagnoulle and R. Jerome, Chem. Commun., 2003, 2904.

35 C. T. Cherian, J. Sundaramurthy, M. Kalaivani, P. Ragupathy, P. Suresh Kumar, V. Thavasi, M. V. Reddy, C. H. Sow, S. G. Mhaisalkar, S. Ramakrishna and B. V. R. Chowdari, J. Mater. Chem., 2012, 22, 12198.

36 G. K. Ramesha and S. Sampath, J. Phys. Chem. C, 2009, 113, 7985.
37 W. J. Cui, F. Li, H. J. Liu, C. X. Wang and Y. Y. Xia, J. Mater. Chem., 2009, 19, 7202.

38 X. X. Ji, X. T. Huang, J. P. Liu, J. Jiang, X. Li, R. M. Ding, Y. Y. Hu, F. Wu and Q. Li, Nanoscale Res. Lett., 2010, 5, 649.

39 J. P. Maranchi, A. F. Hepp and P. N. Kumta, Electrochem. Solid-State Lett., 2003, 6, A198.

40 J. T. Yin, M. Wada, K. Yamamoto, Y. Kitano, S. Tanase and T. Sakai, J. Electrochem. Soc., 2006, 153, A472. 